\title{
BERPIKIR KRITIS SISWA DALAM PENYELESAIAN MATEMATIKA DITINJAU DARI PERBEDAAN TIPE GAYA KOGNITIF REFLEKTIF DAN IMPULSIF
}

\author{
Yuli Aulia Rahayu ${ }^{1}$, Widodo Winarso ${ }^{2}$ \\ 1,2 Jurusan Tadris Matematika, IAIN Syekh Nurjati Cirebon \\ E-mail: yuliauliarahayu@gmail.com; widodoiain@gmail.com
}

\begin{abstract}
ABSTRAK
Esensi dari pembelajaran matematika yakni kemampuan dalam pemecahan masalah matematika. Keberbedaan kemampuan tersebut ditengarai salah satunya yaitu gaya kognitif. Berdasarkan tempo penyelesain masalah matematika yang diperlukan siswa, gaya kognitif terdiri dari tipe reflektif dan impulsif. Sehingga fokus dalam penelitian ini yakni menganalisis kemampuan berpikir kritis siswa dalam penyelesaian masalah matematika berdasarkan perbedaan tipe gaya kognitif reflektif dan impulsif. Studi kausal-komparatif diperlukan untuk menganaisis permasalahan tersebut. Populasi dalam penelitian ini adalah seluruh siswa kelas VII SMPN 1 Susukan Kabupaten Cirebon. Teknik pengmabilan sampel dalam penelitian ini menggunakan teknik purposive sampling dengan jumlah sampel penelitian 31 siswa. Teknik pengumpulan data mengunakan Tes Gaya Kognitif MFFT (Matching Familiar Figures Test) dan Tes uraian (essay) berpikir kritis Matematika. Uji hipotesis yang digunakan adalah uji $\mathrm{t}$ (Independen Samples T Test). Adapun hasil penelitian menunjukkan bahwa, sebaran gaya kognitif siswa di SMPN 1 Susukan Kabupaten Cirebon, didominasi oleh siswa tipe gaya kognitif reflektif (74\% siswa), sedangkan sebagian kecil siswa bertipe gaya kognitif impulsif (26\% siswa). Kemampuan berpikir kritis siswa tipe gaya kognitif reflektif lebih baik jika dibandingkan dengan siswa tipe gaya kognitif impulsif.
\end{abstract}

Kata Kunci: Berpikir Kritis, Pemecahan Masalah, Gaya Kognitif

\begin{abstract}
The essence of mathematics learning is the ability to solve math problems. Differences in ability, one of which is the suspect cognitive style. Based on the cause of the necessary mathematical problems of the students, cognitive style consists of a type of reflection and impulsive. So that the focus of this research is to analyze students' critical thinking skills in solving mathematical problems based on different types of reflective and impulsive cognitive style. Causal-comparative studies are needed to analyze the problem. The population of this study is composed of students of class VII SMPN 1 Susukan Cirebon. While the sample search uses the intentional sampling technique with the number of research samples 31 students. The technique of data collection using the Cognitive Style TMF test (correspondence familiar figures Test) and description Test (essay) Mathematics of critical thinking. The hypothesis test used is the t-test (T-test for independent samples). The results of the research show that the distribution of cognitive styles of students at SMPN 1 Susukan Cirebon, dominated by reflective-type cognitive style students (74\% of students), while a small part of the students type of impulsive cognitive style (26\% of students). Critical thinking ability of reflective type students of cognitive style is better than the type of impulsive cognitive style students
\end{abstract}

Key words: Critical Thinking; Problem Solving; Cognitive Style 


\section{PENDAHULUAN}

Pembelajaran

matematika

mempunyai peran yang sangat penting untuk bekal pengetahuan serta membentuk sikap dan pola pikir siswa. Mata pelajaran Matematika perlu diberikan kepada semua peserta didik mulai dari sekolah dasar sampai dengan jenjang pendidikan tinggi karna matematika untuk membekali peserta didik dengan kemampuan berpikir logis, analitis, sistematis, kritis, dan kreatif, serta kemampuan bekerjasama. Hal tersebut diperlukan agar siswa dapat memiliki kemampuan dalam memperoleh, mengelola dan memanfaatkan informasi dalam hidup bermasyarakat yang selalu terus berkembang (Gouba, 2008).

Peningkatan kualitas pendidikan matematika merupakan hal yang sangat strategis dalam upaya meningkatkan kualitas sumber daya manusia agar memiliki pengetahuan, keterampilan, dan sikap yang bnerorientasi pada peningkatan penguasaan ilmu pengetahuan dan teknologi (Ibad, 2011). Kualitas pendidikan matematika dapat dilakukan dengan melakukan serangkaian pembenahan persoalan yang dihadapi, diantaranya, strategi pembelajaran dan mengubah pembelajaran dari siswa pasif ke siswa aktif. Oleh karena itu, seorang guru harus tepat dalam memilih strategi pembelajaran yang sesuai dengan materi pembelajaran yang akan disampaikan, dan merancang pembelajaran yang menantang agar siswa lebih aktif dalam mengungkapkan ide-ide kreatifnya dan dapat memecahkan masalah secara kolaboratif sehingga siswa dapat memahami materi yang dipelajarinya. (Najichun \& Winarso, 2017)

Manurut Kowiyah (2012), dalam mempelajari matematika diperlukan suatu proses berpikir karena matematika berkenaan dengan struktur dan ide abstrak yang disusun secara sistematis dan logis melalui proses penalaran deduktif. Untuk mengembangkan kemampuan berpikir matematika siswa, seorang guru perlu mendorong siswanya untuk terlibat aktif dalam diskusi, bertanya serta menjawab pertanyaan, berpikir secara kritis, menjelaskan setiap jawaban yang diberikan, serta mengajukan alasan untuk setiap jawaban yang diajukan.

Matematika merupakan mata pelajaran yang berkaitan dengan konsepkonsep. Maka dalam proses pembelajarannya, matematika harus dapat disajikan lebih menarik dan disesuaikan dengan materi yang diajarkan (Winarso \& Karimah, 2017). Hal ini bertujuan agar siswa dapat berperan aktif dalam proses pembelajaran dan tertarik dengan materi yang diajarkan. Ketika siswa dibiarkan dan merasa tidak mampu maka siswa akan menjadi malas untuk mempelajari matematika. Sehingga seorang guru harus secara aktif membimbing dan mengarahkan siswa agar siswa yang mengalami kesulitan dapat lebih tertantang untuk mempelajari matematika.

Menurut Winarso \& Dewi (2017), Berpikir merupakan kegiatan mental yang dihadapi seseorang ketika dihadapkan dengan suatu masalah yang harus dipecahkan. Proses berpikir dapat membangun konsep diri untuk membangun kemampuan berpikir kritis siswa (Winarso \& Supriady, 2016). Berpikir kritis merupakan hal yang penting dalam kehidupan manusia terutama pada saat menghadapi suatu masalah. Melalui berpikir kritis manusia menemukan cara-cara yang dapat dipakai untuk menangani masalahmasalah yang dihadapinya. Kemampuan berpikir kritis matematika siswa dapat dikembangkan dengan memperbanyak pengalaman melalui latihan soal-soal. Sehingga kurang tepat bila pembelajaran matematika dilakukan dengan cara menghafal.Berpikir kritis juga diartikan sebagai aktivitas terampil yang menggunakan logika dalam menyelesaikan masalah, yang terdiri dari kegiatan mengidentifikasi masalah, menemukan solusi yang tepat, menyelesaikan masalah, menganalisis masalah, dan menarik kesimpulan dari penyelesaian masalah (Peter, 2012).

Hal lain yang perlu diperhatikan dalam pembelajaran matematika adalah karakteristik siswa. Karakteristik siswa yang dimaksud di sini adalah gaya kognitif siswa. Gaya kognitif merupakan cara siswa yang khas dalam belajar, baik yang berkaitan 
dengan cara menerima dan mengolah informasi, sikap terhadap informasi, maupun kebiasaan yang berhubungan dengan lingkungan belajar (Daraini, 2012). Seorang guru yang baik tentu tidak hanya melihat keberhasilan siswa berdasarkan nilai yang diperolehnya saja, dan menganggap siswa yang mendapatkan nilai jelek adalah siswa yang tidak bisa, begitupun sebaliknya. Maka seorang guru harus mengetahui dan mencari informasi kenapa siswa tersebut mendapatkan nilai yang jelek. Terkait dengan hal tersebut, informasi penting yang perlu diketahui seorang guru adalah keterkaitan dengan gaya kognitif yang dimiiki siswa.

Siswa merupakan salah satu komponen penting dalam pendidikan. Setiap siswa memiliki karekteristik yang berbeda dengan siswa lainnya. Menurut Skemp (2012), karakteristik siswa adalah yang berhubungan dengan aspek-aspek yang melekat pada diri siswa, seperti: motivasi, bakat, minat, kemampuan awal, gaya belajar, gaya kognitif, kepribadian dan sebagainya. Idealnya di dalam pembelajaran faktor karakteristik siswa harus menjadi salah satu bahan pertimbangan. Namun kenyataannya, kegiatan pembelajaran selama ini mengabaikan perbedaan karakteristik siswa, salah satunya adalah perbedaan pada karakteristik gaya kognitif.

Setiap siswa memiliki cara yang berbeda-beda dalam memahami materi pembelajaran. Ada siswa yang cepat merespon materi pembelajaran, adapula siswa yang lambat merespon materi pembelajaran. Cepat atau lambatnya respon yang diberikan siswa disebut dengan tempo belajar siswa. Berdasarkan konseptual tempo belajar siswa, gaya kognitif dibagi menjadi dua yaitu gaya kognitif tipe reflektif dan gaya kognitif tipe impulsif. Menurut Riding \& Rayner (2013), siswa yang memiliki gaya kognitif reflektif lebih lambat dalam memberikan reaksi terhadap masalah yang diberikan karena ia memerlukan waktu yang relatif lama untuk memikirkan masalah yang diterimanya, sedangkan siswa yang memiliki gaya kognitif impulsif memberikan reaksi yang cepat terhadap masalah yang diterima tanpa perenungan yang mendalam.
Berdasarkan penelitian yang dilakukan oleh Warli pada tahun 2014 yang berjudul "Kreativitas Siswa SMP yang Bergaya Kognitif Reflektif dan Impulsif dalam Memecahkan Masalah Geometri”. Hasil penelitian menunjukkan bahwa profil kreativitas siswa yang bergaya kognitif reflektif dalam memecahkan masalah geometri cenderung tinggi dan profil kreativitas siswa impulsif dalam memecahkan masalah geometri cenderung sangat rendah. Diperoleh jumlah siswa impulsif sebanyak 46 siswa (37\%), sedangkan jumlah siswa reflektif sebanyak 45 siswa (36\%). Hal ini menunjukkan bahwa proporsi siswa yang memiliki karakteristik reflektif atau impulsif sebanyak $73 \%$ lebih besar dibandingkan dengan siswa yang memiliki karakteristik cepat dan tepat/akurat dalam menjawab atau lambat dan kurang tepat/kurang akurat dalam menjawab, yaitu sebanyak $27 \%$. Hal tersebut berarti bahwa gaya kognitif setiap siswa mempengaruhi tingkat kreativitas siswa dalam memecahkan masalah matematika.

Salah satu faktor yang diduga dapat mempengaruhi keberhasilan proses pembelajaran matematika adalah karakteristik siswa (gaya kognitif). Gaya kognitif yang dimiliki setiap siswa berbedabeda. Maka pemahaman yang dimiliki siswa pun berbeda-beda tingkatnnya. Sehingga seorang guru harus bisa mengenal karakteristik yang dimiliki siswanya, dan seorang siswa harus mengenal karakteristik yang dimilikinya. Hal ini bertujuan agar materi pembelajaran dapat tersampaikan dengan baik.

Pada penelitian ini selanjutnya mengkaji tentang apakah ada perbedaan yang signifikansi berpikir kritis dalam penyelesaian masalah matematika antara siswa bergaya kognitif reflektif dengan siswa bergaya kognitif impulsive.

\section{METODE PENELITIAN}

Penelitian ini dilaksanakan di SMP Negeri 1 Susukan, Kecamatan Susukan Kabupaten Cirebon Propinsi Jawa Barat. Waktu pelaksanaan penelitian ini membutuhkan waktu kurang lebih selama 4 bulan. Penelitian ini dilaksanakan pada tahun ajaran 2016/2017. 
Metode penelitian yang di gunakan yakni kuantitatif jenis kausal-komparatif (Creswell \& Creswell, 2017). Fokus dalam penelitian ini mengenai berpikir kritis siswa dalam penyelesain matematika ditinjau dari perbedaan gaya kognitif reflektif dan impulsif. Populasi dalam penelitian ini adalah seluruh siswa kelas VII SMP Negeri 1 Susukan Kabupaten Cirebon yang berjumlah sekitar 360 siswa yang terdiri dari 9 kelas. Cara pengambilan sampel pada penelitian ini adalah dengan menggunakan purposive sampling yaitu teknik pengambilan sampel dengan pertimbangan tertentu (Etikan, Musa \& Alkassim, 2016). Peneliti menganggap bahwa cara pengambilan sampel dengan menggunakan teknik purposive sampling ini sesuai karena pertimbangan-pertimbangan yang dilakukan dalam teknik purposive sampling bisa beragam dan bergantung pada kebutuhan penelitian yang dilakukan. Oleh karena itu terpilih satu kelas untuk dijadikan sampel penelitian yaitu kelas VII-I dengan jumlah sempel penelitian 31 siswa.

Instrumen yang digunakan dalam penelitian ini adalah dua intrumen, yaitu: Tes Uraian dan Tes MFFT (Matching Familiar Figure Test).

Tes adalah serentetan pertanyaan atau latihan serta alat lain yang digunakan untuk mengukur keterampilan, pengetahuan inteligensi, kemampuan atau bakat yang dimiliki oleh individu atau kelompok (Kubiszyn \& Borich, 2015). Tes yang digunakan dalam penelitian ini adalah soal bentuk cerita. Tes uraian diberikan kepada subjek penelitian yang bertujun untuk mengukur kemamampuan berpikir kritis siswa dalam penyelesaikan masalah matematika. Sebelum instrumen digunakan dalam penelitian, instrumen tersebut diuji cobakan terlebih dahulu untuk mengetahui terpenuhi valid atau tidak valid sebagai alat untuk mengumpulkan data yang dapat digunakan sebagai alat penelitian. Uji coba instrumen dilakukan di kelas VII-H di SMP Negeri 1 Susukan Kab. Cirebon. Pengujian ini dimaksudkan untuk mengetahui validitas, reliabilitas, daya pembeda dan tingkat kesukaran dari instrumen penelitian.

Instrumen yang digunakan untuk mengetahui cepat atau lambatnya seseorang dalam merespon (tempo belajar) adalah instrumen Matching Familiar Figure Test (Block, Block \& Harrington, 1974). Adapun kriteria yang diukur untuk mengetahui apakah siswa cenderung memiliki gaya kognitif tipe reflektif atau impulsif adalah sebagai berikut. (a) Siswa tipe reflektif diambil dari kelompok siswa yang catatan waktuya paling lama dan paling cermat (paling banyak benar) dalam menjawab seluruh butir soal. (b) Data yang dicatat meliputi banyaknya waktu yang digunakan siswa pada saat menjawab keseluruhan butir soal $(\mathrm{t})$ dan frekuensi salah atau benarnya jawaban yang diberikan subjek dari keseluruhan butir soal (f).

Tes MFFT (Matching Familiar Figure Test) diberikan kepada calon subjek untuk mendapatkan subjek penelitian yang memiliki gaya kognitif tipe reflektif dan subjek penelitian yang memiliki gaya kognitif tipe impulsif. Soal tes terdiri dari 13 butir soal dengan 6 macam gambar dimana hanya ada satu gambar yang benar-benar sama dengan gambar utama. Hal ini bertujuan agar siswa yang terpilih benarbenar siswa tipe reflektif atau impulsif. Siswa tipe reflektif diambil dari kelompok siswa yang menggunakan waktu paling lama ( $\mathrm{t}>7.28$ menit) dan paling sedikit salah ( $\mathrm{f}<7$ soal) dalam menjawab seluruh butir soal. Sedangkan siswa tipe reflektif diambil dari kelompok siswa yang menggunakan waktu paling cepat $(\mathrm{t}<7.28$ menit $)$ dan paling banyak salah ( $\mathrm{f}>7$ soal) dalam menjawab seluruh butir soal.

Hipotesis dalam penelitian ini merupakan hipotesis komparasional. Uji hipotesis yang digunakan adalah uji $\mathrm{t}$ (Independen Samples T Test) (O'Mahony, 2017). Namun sebelum melakukan pengujian hipotesis, maka diperlukan pengujian prasyarat yang meliputi uji normalitas dan uji homogenitas. Jika data berpikir kritis siswa tersebut berdistribusi normal maka pengujian dilanjutkan dengan uji homogenitas dan uji hipotesis yaitu uji $t$ untuk dua sampel independen. Sebaliknya jika data berpikir kritis siswa yang diperoleh tidak berdistribusi normal maka pengujian dilanjutkan dengan uji homogenitas dan uji hipotesis yaitu uji mann whitney $\mathrm{U}$. 


\section{HASIL DAN PEMBAHASAN}

\section{Hasil Penelitian}

Data tentang hasil penelitian kognitif tipe reflektif dan impulsive pada siswa kelas
VII dengan jumlah sampel penelitian 31 siswa dengan menggunakan instrumen tes MFFT (Matching Familiar Figure Test) dapat dilihat apda Tabel 1.

Tabel 1. Proporsi Gaya Kognitif Reflektif dan Impulsif Siswa

\begin{tabular}{cccc}
\hline Responden & f & t & Gaya Kognitif \\
\hline R_1 & 5 & 6,29 menit & Kognitif Impulsif \\
R_2 & 6 & 6,05 menit & Kognitif Impulsif \\
R_3 & 5 & 7,15 menit & Kognitif Impulsif \\
R_4 & 13 & 13,28 menit & Kognitif Reflektif \\
R_5 & 9 & 8,10 menit & Kognitif Reflektif \\
R_6 & 8 & 7,58 menit & Kognitif Reflektif \\
R_7 & 8 & 10,30 menit & Kognitif Reflektif \\
R_8 & 12 & 14,10 menit & Kognitif Reflektif \\
R_9 & 9 & 9,25 menit & Kognitif Reflektif \\
R_10 & 3 & 7,25 menit & Kognitif Impulsif \\
R_11 & 10 & 9,15 menit & Kognitif Reflektif \\
R_12 & 12 & 10,28 menit & Kognitif Reflektif \\
R_13 & 9 & 14,28 menit & Kognitif Reflektif \\
R_14 & 8 & 11,56 menit & Kognitif Reflektif \\
R_15 & 10 & 15,00 menit & Kognitif Reflektif \\
R_16 & 10 & 14,28 menit & Kognitif Reflektif \\
R_17 & 5 & 7,13 menit & Kognitif Impulsif \\
R_18 & 11 & 14,29 menit & Kognitif Reflektif \\
R_19 & 9 & 15,00 menit & Kognitif Reflektif \\
R_20 & 13 & 14,29 menit & Kognitif Reflektif \\
R_21 & 3 & 6,50 menit & Kognitif Impulsif \\
R_22 & 7 & 13,33 menit & Kognitif Reflektif \\
R_23 & 11 & 12,49 menit & Kognitif Reflektif \\
R_24 & 7 & 10,55 menit & Kognitif Reflektif \\
R_25 & 8 & 9,45 menit & Kognitif Reflektif \\
R_26 & 7 & 15,00 menit & Kognitif Reflektif \\
R_27 & 8 & 8,27 menit & Kognitif Reflektif \\
R_28 & 6 & 6,58 menit & Kognitif Impulsif \\
R_29 & 4 & 7,25 menit & Kognitif Impulsif \\
R_30 & 13 & 15,00 menit & Kognitif Reflektif \\
R_31 & 9 & 11,34 menit & Kognitif Reflektif \\
\hline
\end{tabular}

Berdasarkan Tabel 1, dari 31 responden penelitian terdapat 23 siswa cenderung memiliki gaya kognitif tipe reflektif yaitu kelompok siswa yang menggunakan waktu lebih lama ( $t \geq 7.28$ menit) dan frekuensi paling banyak menjawab soal dengan benar ( $f \geq 7$ soal) dan 8 siswa kelompok gaya kognitif tipe impulsif yaitu kelompok siswa yang menggunakan waktu lebih cepat $(t<7.28$ menit) dan frekuensi paling sedikit menjawab soal dengan benar ( $f<7$ soal). sehingga sebagian besar siswa kelas VII SMP Negeri 1 Susukan Kabupaten Cirebon cenderung memiliki gaya kognitif tipe reflektif sebesar $74 \%$, Sedangkan sebagian kecil siswa cenderung memiliki gaya kognitif tipe impulsif sebesar $26 \%$.

Selanjutnya data hasil penelitian terkait dengan berpikir kritis siswa dalam penyelesaian matematika dapat dilihat pada Tabel 2. 
Tabel 2. Hasil analisis Descriptif Kemampuan Berpikir Kritis Siswa

\begin{tabular}{cccccccc}
\hline \multicolumn{2}{c}{ Variasi Statistik } & N & \multicolumn{6}{c}{ Mean } & Std. Deviation & Std. Error & Minimum & Maximum \\
\hline \multirow{3}{*}{ Berpikir Kritis } & Implusif & 8 & 34,12 & 5,59 & 1,97 & 24 & 42 \\
& Reflektif & 23 & 63,82 & 14,85 & 3,09 & 42 & 93 \\
& Total & 31 & 56,16 & 18,53 & 3,32 & 24 & 93 \\
\hline
\end{tabular}

Secara umum, Tabel 2 menunjukkan terdapat perbedaan berpikir kritis siswa terhadap penyelesaian masalah matematika antar tipe gaya kognitif. Tabel 2 juga menunjukkan siswa yang cenderung memiliki gaya kognitif tipe impulsif memperoleh nilai rata-rata sebesar 34,12 , datandar deviasi sebesar 5,59, nilai minimum sebesar 24 dan nilai maksimum sebesar 42. Sedangkan siswa yang cenderung memiliki gaya kognitif tipe reflektif memperoleh nilai mean sebesar 63,82 , standar deviasi sebesar 14,58 , nilai minimum sebesar 42 dan nilai maksimum sebesar 93. Dengan demikian dapat dimaknai bahwa kemampuan berpikir kritis siswa dalam penyelesaian matematika berdasarkan gaya kognitif tipe impulsif menurut klasifikasi rating tergolong kurang baik, sedangkan bagi siswa gaya kognitif tipe reflektif menurut klasifikasi rating tergolong baik.

Analisis berikutnya dilakukan pengujian hipotesis. Namun sebelum dilakukanya pengujian, maka di perlukanya persyaratan uji hipotesis. Hal tersebut digunakan untuk mengetahui apakah analisis data dapat dilanjut atau tidak. Pertama, uji normalitas digunakan untuk mengetahui apakah populasi data yang diperoleh melalui tes berpikir kritis siswa dalam menyelesaikan matematika berdistribusi normal atau tidak. Pengujian mengunakan Shapiro-Wilk. Adapun persyaratan uji hipotesis (uji normalitas) dapat dilihat pada Tabel 3.

Tabel 3. Hasil Analisis Uji Normalitas

\begin{tabular}{lcccrrr}
\hline \multirow{2}{*}{ Variasi Satistik } & \multicolumn{3}{c}{ Kolmogorov-Smirnov $^{\mathrm{a}}$} & \multicolumn{3}{c}{ Shapiro-Wilk } \\
& Statistic & df & Sig. & Statistic & df & \multicolumn{1}{c}{ Sig. } \\
\hline Berpikir Kritis & 0,084 & 31 & $0,200^{*}$ & 0,966 & 31 & 0,426 \\
\hline
\end{tabular}

*. This is a lower bound of the true significance.

a. Lilliefors Significance Correction

Tabel 4. Hasil Analisis Uji Homogenitas

\begin{tabular}{llrrrr}
\hline & Variasi Statistik & Levene Statistic & df1 & df2 & \multicolumn{1}{c}{ Sig. } \\
Based on Mean & 0,460 & 2 & 90 & 0,633 \\
Based on Median & 0,443 & 2 & 90 & 0,644 \\
Based on Median and with & 0,443 & 2 & 87,682 & 0,644 \\
& $\begin{array}{l}\text { adjusted df } \\
\text { Based on trimmed mean }\end{array}$ & 0,472 & 2 & 90 & 0,626 \\
\hline
\end{tabular}


Dari Tabel 3 dapat diketahui hasil perhitungan uji normalitas dengan menggunaan tingkat kepercayaan $\alpha=0,05$ diperoleh nilai signifikan (Sig.) pada uji normalitas Kolmogorov-Smirnov dengan nilai Sig. 0,200 >0,05. Hal itu berarti data berpikir kritis dalam penyelesain matematika berdistribusi normal.

Kedua, uji homogenitas digunakan untuk mengetahui apakah populasi data yang diperoleh melalui tes berpikir kritis dalam menyelesaikan matematika tersebut memiliki varian populasi data sama atau tidak. Hasil analisis uji homogenitas dapat dilihat pada Tabel 4. Berdasarkan Tabel 4, diperoleh nilai Based on Mean pada tabel Levene Statistic sebesar 0,633. Nilai tersebut lebih besar dari pada nilai $\alpha(\alpha=0,05)$. Karena nilai $P$-value $>\alpha$, maka $H_{0}$ diterima. dapat dimaknai bahwa data penelitian berpikir kritis dalam penyelesain matematika merupakan data yang homogen.

Setelah melakukan uji prayarat, maka dilakukan pengujian hipotesis. Dimana pengujian hipotesis mengunakan Independent Sampel T-Test. didapat hasil data penelitian seperti Tabel 5 .

Tabel 5. Hasil analisis Uji Hipotesis dengan Independent Samples T-Test

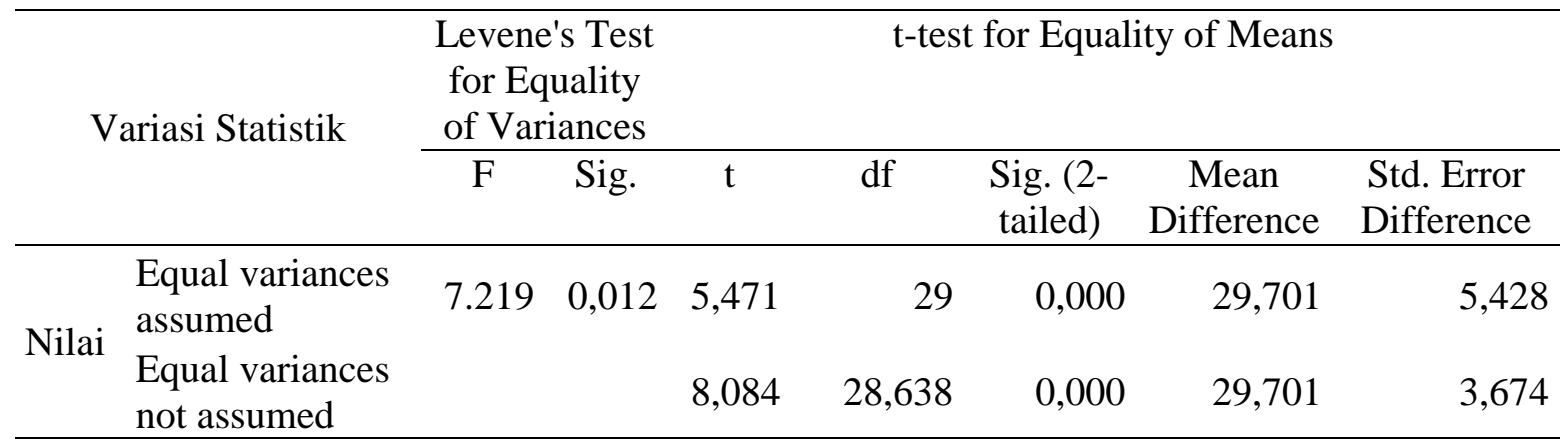

Berdasarkan tabel 5, didapat Nilai $t_{\text {hitung }}>t_{\text {tabal }}(5,471>2,045)$ dengan signifikansi $0,000<0,05$ maka $H_{0}$ ditolak. Dapat disimpulkan bahwa terdapat perbedaan berpikir kritis dalam penyelesaian matematika antara siswa gaya kognitif tipe reflektif dengan kelompok siswa gaya kognitif tipe impulsif.

\section{Pembahasan}

Gaya kognitif berdasarkan konseptual tempo belajar siswa dibagi menjadi dua yaitu gaya kognitif tipe reflektif dan gaya kognitif tipe impulsive (Riding \& Cheema, 1991). Sedangkan menurut Firestone \& Douglas (1977) jenis siswa tipe reflektif yakni siswa yang lebih mempertimbangkan banyak alternatif sebelum merespon sehingga tinggi kemungkinan respon yang diberikan cenderung benar. Sedangkan, siswa tipe impulsif adalah siswa yang dengan cepat merespon suatu situasi, namun respon yang diberikan cenderung salah. sejalan dengan hal tersebut, menurut Warli (2009), terdapat dua aspek penting yang perlu diperhatikan dalam mengukur gaya kognitif tipe reflektif dan impulsif yaitu aspek waktu yang digunakan siswa dalam mengerjakan soal dan aspek frekuensi jawaban yang diberikan siswa.

Berdasarkan hasil penyebaran tes MFFT (Matching Familiar Figure Test) gaya kognitif tipe reflektif dan impulsif siswa di kelas VII SMP Negeri 1 Susukan Kabupaten Cirebon dapat disimpulkan bahwa sebagian besar siswa cenderung memiliki gaya kognitif tipe reflektif dan sebagian kecil lainnya siswa cenderung memiliki gaya kognitif tipe impulsif.

Dari hasil pengamatan selama penelitian diketahui bahwa siswa yang memiliki gaya kognitif tipe reflektif lebih membutuhkan waktu yang lama untuk mengerjakan soal, dengan penuh hati-hati dan didasarkan atas pertimbangan tertentu. Siswa tipe relektif lebih memilih membaca soal secara berulang untuk memahami soal, sehingga jawaban yang diberikan siswa tipe reflektif cenderung benar. Selain itu siswa 
tipe reflektif juga terlihat lebih serius dalam mengerjakan soal. Lain halnya dengan siswa yang memiliki gayakognitif tipe impulsif, siswa tipe impulsif ini terlihat lebih cepat dalam mengerjakan soal dibandingkan dengan siswa tipe reflektif. Siswa impulsif tipe juga spontan dalam menjawab soal dan berdasarkan apa yang ia lihat pertama kali tanpa mempertimbangkan kebenaran atas jawaban yang ia berikan. Sehingga jawaban yang diberikan siswa tipe impulsif cenderung salah. Berdasarkan hasil penelitian tersebut dapat disimpulkan bahwa siswa tipe reflektif lebih membutuhkan waktu yang lebih lama untuk menjawab soal. Sedangkan siswa tipe impulsif adalah siswa yang dengan cepat dalam memberikan respon atau jawaban.

Menurut Ennis dalam Winarso \& Dewi (2017), berpikir kritis dalam penyelesain matematika merupakan pemikiran yang masuk akal dan reflektif yang berfokus untuk memutuskan apa yang mesti dipercaya atau dilakukan. Ciri-ciri seseorang disebut pemikir kritis adalah apabila menyelesaikan suatu masalah berdasarkan tujuan, menganalisis, menggeneralisasikan, mengorganisasikan ide berdasarkan fakta/ informasi yang ada, serta dapat menarik kesimpulan dalam menyelesaikan masalah tersebut secara sistematik dengan argument yang benar.

Berdasarkan hasil penelitian bahwa kemampuan berpikir kritis siswa dalam penyelesaian matematika berdasarkan gaya kognitif tipe impulsif menurut klasifikasi rating tergolong kurang baik, sedangkan bagi siswa gaya kognitif tipe reflektif menurut klasifikasi rating tergolong baik. kondisi tersebut, di perkuat dari hasil pengamatan selama penelitian terlihat bahwa siswa kurang memahi konsep dasar matematika terutama pada pokok bahasan aritmetika sosial. Hal ini dapat diklarifikasi melalui hasil jawaban tes lembar kerja siswa (LKS). Dalam pengerjaan soal matematika, pemahaman konsep dasar sangat dibutuhkan untuk membantu siswa dalam proses pengerjaan soal. Kurangnya pemahaman konsep dasar matematika siswa dapat mempengaruhi kemampuan berpikir kritis siswa. Secara teori, salah satu faktor yang dapat mempengaruhi berpikir kritis siswa adalah perkembangan intelektual. Setiap orang memiliki tingkatan kecerdasan yang berbeda-beda. Perbedaan kecerdasan siswa dapat mempengaruhi kemampuan berpikir kritis siswa (Terenzini, dkk., 1995). Faktor lain yang dapat mempengaruhi berpikir kritis siswa dalam penyelesain matematika adalah kebiasaan. Kebiasaan disini adalah kebiasaan yang dilakukan siswa dalam pembelajaran matematika, seperti kebiasaan melakukan latihan soal-soal matematika. Kebiasaan mengerjakan latihan soal matematika dapat membantu siswa untuk meningkatkan dan mengembangkan kemampuan berpikir kritis siswa.(Bailin, dkk., 1999)

$$
\text { Menurut Winarso }
$$

penyelesaian masalah (problem solving) merupakan pendekatan dengan menggunakan langkah-langkah, dimana langkah-langkah berikutnya sampai penyelesaian akhir bersifat kuantitatif yang umum, sedangkan lagkah-langkah berikutnya sampai dengan penyelesaian akhir lebih bersifat kualitatif dan spesifik. Soal matematika disebut bukan masalah matematika, apabila siswa dapat segera mengetahui metode/prosedur untuk menjawab soal atau siswa tidak berkeinginan untuk menyelesaikan soal tersebut. Untuk memecahkan atau menyelesaikan suatu masalah matematika siswa perlu melakukan kegiatan mental (berfikir) yang lebih banyak dan kompleks dari pada kegiatan mental yang siswa lakukan pada saat menyelesaikan soal yang bukan masalah matematika.

Sejalan dengan hal tersebut, hasil pengamatan selama penelitian terlihat bahwa dalam proses pengerjaan soal matematika pada pokok bahasan aritmetika sosial, sebagian besar siswa mengerjakan soal matematika sesuai dengan langkah-langkah penyelesaian masalah yaitu dengan menentukan informasi yang ada di dalam soal, menentukan apa yang ditanyakan dalam soal, tahapan dalam penyelesaian soal dan memberikan kesimpulan jawaban. Pengerjaan soal matematika yang sesuai dengan langkah-langkah penyelesaian masalah dapat mempengaruhi hasil 
pembelajaran matematika. Karena dengan tahapan-tahapan penyelesaian masalah tersebut siswa dapat mengembangkan kemampuan dalam penyelesaian masalah matematika. Selain itu, siswa yang dapat memahami informasi dalam suatu masalah, siswa dapat menentukan strategi yang dapat digunakan untuk menyelesaian masalah matematika. Namun ada pula siswa yang tidak menggunakan langkah-langkah dalam penyelesaian masalah, ia hanya menggunakan tahapan dalam penyelesaian masalah. Hal ini disebabkan oleh beberapa faktor seperti kemampuan berpikir siswa. Kemampuan berpikir siswa yang berbedabeda tingkatannya akan memicu perbedaan kemampuan siswa dalam mengerjakan soal matematika (Hiebert \& Lefevre, 1986).

Sedangkan pada hasil uji hipotesis berpikir kritis siswa dalam penyelesaian masalah matematika berdasarkan perbedaan gaya kognitif reflektif dan impulsif diperoleh nilai $t_{\text {hitung }}>t_{\text {tabel }}$ yaitu $(5,471>2,045)$ dengan signifikansi $0,000<0,05$ maka $H_{0}$ ditolak. Jadi, terdapat perbedaan berpikir kritis terhadap penyelesaia masalah matematika antara siswa yang memiliki gaya kognitif tipe reflektif dengan siswa yang memiliki gaya kognitif tipe impulsif. Perbedaan tersebut dapat dilihat dari hasil nilai rata-rata siswa. Siswa tipe reflektif memperoleh nilai ratarata lebih tinggi sebesar 63,83 yang termasuk dalam kriteria baik sebanyak 23 orang siswa. Sedangkan siswa tipe impulsif memperoleh nilai rata-rata sebesar 34,13 yang termasuk dalam kriteria kurang sebanyak 8 orang siswa.

Berdasarkan pembahasan tentang perbandingan berpikir kritis siswa terhadap penyelesaian masalah matematika berdasarkan gaya kognitif tipe reflektif dan impulsif, dapat diketahui bahwa berpikir kritis terhadap penyelesaian masalah matematika siswa yang cenderung memiliki gaya kognitif tipe reflektif lebih baik dibandingkan dengan siswa yang cenderung memiliki gaya kognitif tipe impulsive. hal tersebut sejalan dengan hasil penelitian Allinson \& Hayes (1996) dalam kajian The cognitive style index.

\section{SIMPULAN DAN SARAN}

Berdasarkan hasil analisis dan penelitian mengenai studi komparatif terhadap berpikir kritis dalam penyelesain matematika ditinjau dari gaya kognitif reflektif dan impulsif, dapat disimpulkan: pertama, Sebaran gaya kognitif siswa tipe reflektif dan impulsif diperoleh dari hasil tes MFFT (Matching Familiar Figure Test). Berdasarkan hasil penelitian didapat bahwa persentase gaya kognitif siswa tipe reflektif lebih tinggi yaitu sebesar $74 \%$ dibandingkan dengan persentase gaya kognitif siswa tipe impulsif yaitu sebesar 26\%. Hal ini menunjukkan bahwa sebaran gaya kognitif siswa kelas VII di SMP Negeri 1 Susukan Kabupaten Cirebon didominasi oleh siswa yang cenderung memiliki gaya kognitif tipe reflektif.

Kedua, kemampuan berpikir kritis siswa dalam penyelesaian matematika berdasarkan pada perbedaan gaya kognitif tipe impulsif menurut klasifikasi rating tergolong kurang baik, sedangkan bagi siswa gaya kognitif tipe reflektif menurut klasifikasi rating tergolong baik.

Ketiga, perbedaan berpikir kritis siswa terhadap penyelesaian masalah matematika berdasarkan gaya kognitif tipe reflektif dan impulsif diperoleh dari uji $t$. Berdasarkan hasil penelitian diperoleh nilai $t_{\text {hitung }}>t_{\text {tabel }}$ yaitu $(5,471>2,045)$ dan signifikansi $0,000<0,05$ maka $H_{0}$ ditolak. Jadi terdapat perbedaan berpikir kritis terhadap penyelesaia masalah matematika antara kelompok siswa yang memiliki gaya kognitif tipe reflektif dengan kelompok siswa yang memiliki gaya kognitif tipe impulsif. Artinya bahwa berpikir kritis terhadap penyelesaian masalah matematika kelompok siswa yang cenderung memiliki gaya kognitif tipe reflektif lebih baik dibandingka dengan kelompok siswa yang cenderung memiliki gaya kognitif tipe impulsif.

Sebagai tindak lanjut dari hasil penelitian, berikut beberapa saran yang diharapkan dapat memberi sumbangan pemikiran untuk meningkatkan kemampuan siswa dalam penyelesain matematika. Pada proses pembelajaran matematika, hendaknya 
dapat membangun kemampuan berpikir kritis dalam penyelesain soal/tes matematika. Dalam proses pembelajaran matematika dikelas, hendaknya guru mempertimbangkan dan memperbanyak pengunaan soal berpikir kritis untuk meningkatkan kemampuan pemecahan masalah matematika. Selan itu, kemampuan diagnostik guru terhadap kecenderungan gaya kognitif siswa dapat memberikan kontribusi dalam penyusunan rencana dan strategi mengajar guru. sehingga melalui kajian ini, digarapkan memberikan mafaat dan daya dukung secara praktis terhadap pembelajaran matematika di sekolah.

\section{DAFTAR RUJUKAN}

Allinson, C. W., \& Hayes, J. (1996). The cognitive style index: A measure of intuition-analysis for organizational research. Journal of Management studies, 33(1), 119-135.

Bailin, S., Case, R., Coombs, J. R., \& Daniels, L. B. (1999). Conceptualizing critical thinking. Journal of curriculum studies,31(3), 285-302.

Block, J., Block, J. H., \& Harrington, D. M. (1974). Some misgivings about the Matching Familiar Figures Test as a measure of reflectionimpulsivity. Developmental Psychology, 10(5), 611.

Creswell, J. W., \& Creswell, J. D. (2017). Research design: Qualitative, quantitative, and mixed methods approaches. Sage publications.

Daraini, R. (2012). Pengaruh Pembelajaran Berbasis Multimedia dan Gaya Kognitif Terhadap Kemampuan Pemecahan Masalah Matematika. Jurnal Teknologi Pendidikan, 5(02), 236-243.

Etikan, I., Musa, S. A., \& Alkassim, R. S. (2016). Comparison of convenience sampling and purposive sampling. American Journal of Theoretical and Applied Statistics, 5(1), 1-4.

Firestone, P., \& Douglas, V. I. (1977). The effects of verbal and material rewards and punishers on the performance of impulsive and reflective children. Child study journal, 7(2), 71-78.

Gouba, L. (2008). The importance of mathematics in everyday life. African Institute for mathematical Sciences, 6.

Hiebert, J., \& Lefevre, P. (1986). Conceptual and procedural knowledge in mathematics: An introductory analysis. Conceptual and procedural knowledge: The case of mathematics, 2, 1-27.

Ibad, M. (2011). Eksperimentasi Pembelajaran Matematika Metode Kooperatif Tipe Student Teams Achievement Divisions (STAD) dan Metode Kooperatif Tipe Numbered Heads Together (NHT) Ditinjau dari Gaya Belajar Siswa (Doctoral dissertation, Universitas Sebelas Maret).

Kubiszyn, T., \& Borich, G. (2015). Educational testing and measurement. John Wiley \& Sons Incorporated.

Najichun, M., \& Winarso, W. (2017). Hubungan Persepsi Siswa tentang Guru Matematika dengan Hasil Belajar Matematika Siswa. Jurnal Psikologi, 15(2), 143-150.

O'Mahony, M. (2017). Sensory evaluation of food: statistical methods and procedures. Routledge.

Peter, E. E. (2012). Critical thinking: Essence for teaching mathematics and mathematics problem solving skills. African Journal of Mathematics and Computer Science Research, 5(3), 39-43.

Riding, R., \& Cheema, I. (1991). Cognitive styles - an overview and 
integration. Educational

psychology, 11(3-4), 193-215.

Riding, R., \& Rayner, S. (2013). Cognitive styles and learning strategies: Understanding style differences in learning and behavior. Routledge.

Skemp, R. R. (2012). The psychology of learning mathematics: Expanded American edition. Routledge.

Terenzini, P. T., Springer, L., Pascarella, E. T., \& Nora, A. (1995). Influences affecting the development of students' critical thinking skills. Research in higher education, 36(1), 23-39.

Warli, W. (2014). Kreativitas Siswa SMP yang Bergaya Kognitif Reflektif atau Impulsif dalam Memecahkan Masalah Geometri.Jurnal Pendidikan dan Pembelajaran (JPP), 20(2), 190-201.

Winarso, W. (2014). Problem Solving, Creativity dan Decision Making Dalam Pembelajaran Matematika. Eduma: Mathematics Education Learning and Teaching, 3(1).1-1

Winarso, W., \& Dewi, W. Y. (2017). Berpikir kritis siswa ditinjau dari gaya kognitif visualizer dan verbalizer dalam menyelesaikan masalah geometri. Beta Jurnal Tadris Matematika, 10(2), 117-133.

Winarso, W., \& Karimah, S. A. (2017). The Influence Of Implementation BrainFriendly Learning Through The Whole Brain Teaching To Students' Response and Creative Character In Learning Mathematics. Jurnal Pendidikan dan Pengajaran, 50(1), 10-19.

Winarso, W., \& Supriady, D. (2016). Menilai Prestasi Belajar melalui Penguatan Self Regulated Learning dan Kecerdasan Emosional Siswa pada Pembelajaran Matematika. Jurnal Didaktik Matematika, 3(2).54-66. 